\title{
倒立振子の姿勢制 御
}

\author{
一一質量の横方向移動による安定化—— \\ 林. 節 八*.嘉 納 秀、明* . 增 淵 正 美* \\ Postural Control of the Inverted Pendulum \\ - Stabilization by Moving Weight Horizontally-
}

Setsuya HaYAshi*. Hideaki-KAnOH* and Masami MasubuchI*

This paper presents a stabilization control of inherently unstable systems in their nature. An inverted pendulum which is a typical, unstable mechanical system, is considered and stabilized by moving a weight horizontally through a feedback control. A stabilization problem in this system coresponds to that in the postural control of a man.

It is shown that, so far as the dry friction at the bearings etc. is negligible, this inverted pendulum is stabilizable when the linearized. system is controlable and observable. At the experiment, the output, the weight position $r$ and the pendulum angle $\theta$, and the estimated state $(\dot{r}, \dot{\theta})$ by a minimum order observer or an-approximate differentiator are fed back. Experimental results show that stabilization was posible in spite of the existence of the dry friction at the bearings etc..

\section{1. まえがき}

不安定な制御対象をフ:イードバック制御によって安 定化させる問題は, 古くからよく取上げられてきた。 倒立振子の安定化制御はその一つの例である. 元来, 倒立振子を安定に倒立させる方法は, 支点を移動させ る方法（たとえば，Fig. 1 (a)）と内部で質量を相対 的に移動させる方法（たとえば, Fig. 1(b)，(c)) と の二つが考えられる.内部で質量を移動させる形式の 倒立振子は, 人間などにおける姿勢制御のモデルとし て考えるととができる．たとえば，Fig. 1(b)の括む りを左右に移動させる形式の倒立振子は, 人が重い棒 をもって綱渡りするときの左右の姿勢制御を，棒の上

†第 5 回制御理論シンポジウムで発表 (昭 51 ・5)

* 大阪大学工学部 吹田市字山田上

* Faculty of Engineering, Osaka University, Suita (Received October 16, 1976)

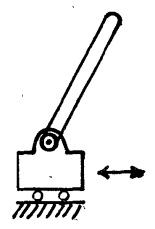

(a)

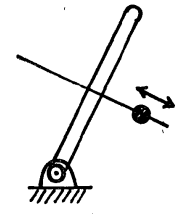

(b)

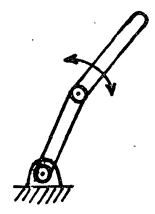

(c)
Fig. 1 Inverted pendulums

下運動を無視してモデル化したすのと考えるととがで きる.

支点を移動させる形式の倒立振子は, 古くから多く の研究があるが，内部で質量を移動させる形式のあの については，まだ少ないようである.Fig. 1(b), (c) は, 内部で質量を移動させる形式のうち, 最む基本的 なむのであるが, 従来の研究としては, 二足歩行のモ デルとして倒立二重振子 Fig. 1(c) を解析している むの ${ }^{1) ~ 3)}$ ，上部振子の重心がその回転軸に一致する場 合を支点移動形と比較して取扱っているもの4などが ある. Fig: 1(b) の执すりを左右に移動させる形式の あのについては，まだ研究されていない.

以上の観点から，著者らは倒立振子の姿勢制御に関 して最む基本的な形式である，おむりを左右に移動さ せる方法による姿勢制御について，理論的かつ実験的 㭘討を行った。

\section{2. 主な記号}

$r:$ 招もりの中央からの移動距離 [m]

$\theta:$ 倒立振子の傾き角 [rad〕

$u$ : 直流電力増幅器の入力端電圧 [V]

$m_{1}$ ：倒立振子のおもり以外の部分の質量〔kg〕

$l_{1}$ : 倒立振子のおむり以外の部分の重心の高さ

$I_{1}{ }^{\prime}$ : 倒立振子のおむり以外の部分の重心のまわり 
の慣性能率 $\left[\mathrm{kg} \cdot \mathrm{m}^{2} 〕\right.$

$I_{1}=m_{1} l_{1}^{2}+I_{1}^{\prime} \quad\left[\mathrm{kg} \cdot \mathrm{m}^{2}\right]$

$m_{2}$ ：移動する扔むりの質量〔kg〕

$l_{2}:$ 捛むりの重心の通る軌道の高さ〔m〕

$I_{2}{ }^{\prime}$ : 抒むりの重心のまわりの慣性能率 $\left[\mathrm{kg} \cdot \mathrm{m}^{2}\right]$

$I_{2}=m_{2} l_{2}{ }^{2}+I_{2^{\prime}} \quad\left[\mathrm{kg} \cdot \mathrm{m}^{2}\right]$

$m_{2 a}$ : 駆動系のおむり以外の部分の等佂質量 [kg〕 $m_{2 b}$ : 駆動系の抒むり以外の部分の等洒定数

$\lceil\mathrm{kg} \cdot \mathrm{m}\rceil$

$m_{a}=m_{2}+m_{2 a} \quad$ 〔kg

$m_{b}=m_{2} l_{2}+m_{2 b} \quad[\mathrm{~kg} \cdot \mathrm{m}]$

$c_{1}$ : 倒立振子の支持軸受の粘性摩擦定数

$\left\lceil\mathrm{kg} \cdot \mathrm{m}^{2} / \mathrm{sec}\right\rceil$

$C_{1 s}$ ：倒立振子の支持軸受に拈ける固体摩擦による モーメント $[\mathrm{N} \cdot \mathrm{m}]$

$c_{2}$ ：扔むりを駆動する装置各部の粘性摩擦と直流 電動機の逆起電力効果とを含む等価粘性摩摖 定数 $[\mathrm{kg} / \mathrm{sec}]$

$C_{2 s}$ : 駆動系の等価固体摩擦力 [N]

$G$ : 直流電力増幅器の入力端から見たゲイン定数

$[\mathrm{N} / \mathrm{V}]$

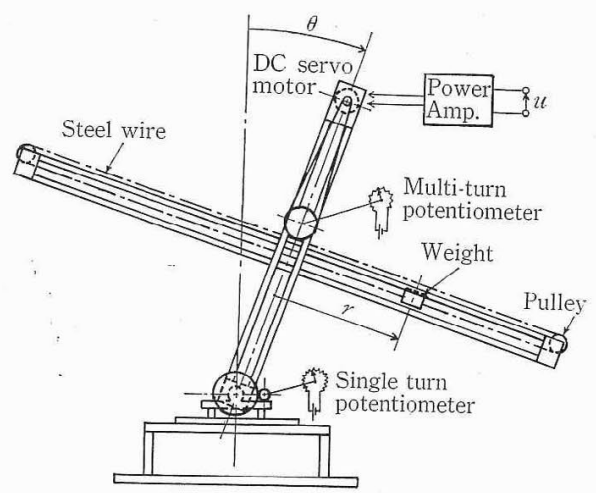

Fig. 2. Experimental system

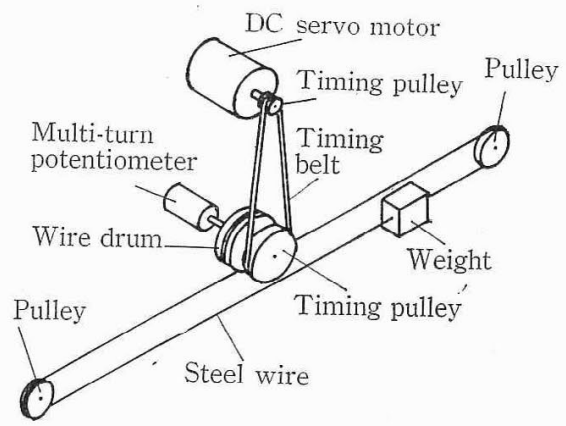

Fig. 3 Weight driving system

$$
\begin{aligned}
g & : \text { 重力加速度 } 〔 \mathrm{~m} / \mathrm{sec}^{2} 〕 \\
I & =I_{1}+I_{2} \quad\left\lceil\mathrm{~kg} \cdot \mathrm{m}^{2} 〕\right. \\
M_{0} & =m_{1} l_{1}+m_{2} l_{2} \quad\lceil\mathrm{~kg} \cdot \mathrm{m}\rceil \\
D & =m_{a} I-m_{b}{ }^{2}
\end{aligned}
$$

\section{3. 実験系と基礎方程式}

本研究の対家とするシステムは，Fig. 2 亿示すよ うに，支持台に取付りられた軸受で支えられる倒立振 子（高さ $1.09 \mathrm{~m}$ ) が，左右に移動しうる扔もりここれ を駆動する他励直流電動機および伝達系とをその内部 に含む電気 一機械系である．おすりを駆動する部分の 概略図を，Fig. 3 に示す，抒むりはタイミングベル トおよびスチールワイヤを介して駆動される，電動機 は $50 \mathrm{~W}$ の直流サーボモータで電機子制御を行ってお り, 界磁側は直流 $100 \mathrm{~V}$ 電源, “電機子側は直流電力 增幅器に接続され, その入力端電圧 $u$ 〔V〕がこのシ ステムの操作量である. 電力增幅器は出力 $\pm 40 \mathrm{~V}$, $\pm 5 \mathrm{~A}, 200 \mathrm{~W}$ のハイブリッド IC パワーアンプを用 いている、抢もりの中央加らの距離を $r[\mathrm{~m}]$ 倒立振 子の傾き角を $\theta[\mathrm{rad}]$ とすると，乙のシステムは $[r$ ， $\theta, \dot{r}, \dot{\theta}]$ 老状態量とする 4 次系であり，乙れを制御す るうえでこれらの状態量をすべて検出するのが望まし いが困難なので，ここでは出力として $r$ と $\theta$ を選び， とすにポテンショメータを用いて検出している，安定 に倒立している状態の倒立振子の外景を Photo. 1,

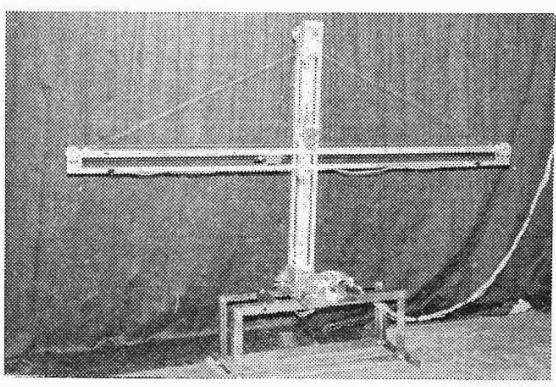

Photo. 1 View of the experimental system

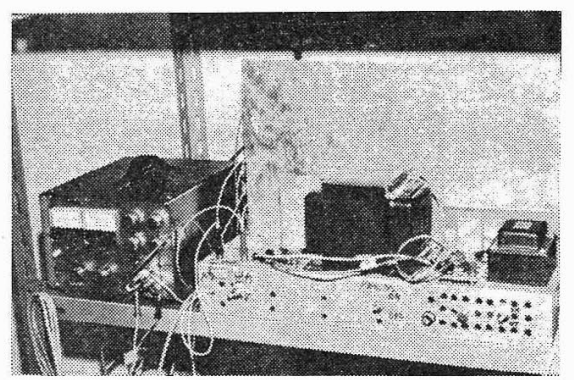

Photo. 2 View of the power amplifier and power supplies $(\mathrm{DC} \pm 10 \mathrm{~V}$, and $\mathrm{DC} 100 \mathrm{~V})$ 
電力増幅器ならびに電源を Photo. 2 亿示す.

実験装置の製作に当っては,つぎの諸点を考慮した. 操作部の選択については, 線形特性を考虑して, 直流 サーボモータの電機子制御方式を採用した。移動質量 に働く力を直接に操作量にするのが理想的であり，電 磁粉体クラッチを用いれば可能であるが，重量が大に なる欠点があった．また，モー夕を用いる場合が，力 を操作量とする場合に速度のフィードバックが付け加 わっているのと等価であり，解析上ほとんで同じであ るてとも考慮した，倒立振子の構造については，4
】節で示す可制御条件を考慮して, 移動質量の軌道 が，倒立振子の支点に対する打撃の中心から十分離れ た高さになるようにした，すなわち軌道の高さが，重 心よりできるだけ低くなるようにした．伝達系につい ては，歯車はバックラッシが間題になるので，タイミ ングベルトとワイアによる方式を採用した。

電動機の電気的時定数が十分小さく, ベルトとワイ アの伸びがないと仮定し, 軸受などの粘性摩擦と固体 摩擦を考慮すると，実験系はつぎの微分方程式で記述 される。

$$
\begin{aligned}
& {\left[\begin{array}{cc}
m_{2} l_{2}+m_{2 b} & I_{1}+I_{2}+m_{2} r^{2} \\
m_{2}+m_{2 a} & m_{2} l_{2}+m_{2 b}
\end{array}\right]\left[\begin{array}{l}
\ddot{r} \\
\ddot{\theta}
\end{array}\right]=\left[\begin{array}{c}
-c_{1} \dot{\theta}-C_{1 s}^{1} \operatorname{sgn}(\dot{\theta})+\left(m_{1} l_{1}+m_{2} l_{2}\right) g \sin \theta+m_{2} g r \cos \theta-2 m_{2} r \dot{r} \dot{\theta} \\
-c_{2} \dot{r}-C_{2 s} \operatorname{sgn}(\dot{r})+m_{2} g \sin \theta+m_{2} r \dot{\theta}^{2}+G u
\end{array}\right]} \\
& \left(\cdot=\frac{d}{d t}, \quad \cdot \cdot=\frac{d^{2}}{d t^{2}}\right)
\end{aligned}
$$

なお，おむりに働く力を操作量とする理想的な操作 部をむつ場合は，(1)式で $m_{2 a}=m_{2 b}=0$ とし， $c_{2}$ に 逆起電力効果によるむのを含めず, $G u$ を操作量(力) と考えればよい。したがって本研究の解析は，乙のよ うな考慮のあとでおすりに働く力を操作量とする場合 にむ適用できる。

簡単のため, 以下つぎの記号を用いる.

$$
\begin{aligned}
& m_{a}=m_{2}+m_{2 a}, \quad m_{b}=m_{2} l_{2}+m_{2 b}, \\
& M_{0}=m_{1} l_{1}+m_{2} l_{2}, \quad I=I_{1}+I_{2}, \quad D=m_{a} I-m_{b}{ }^{2}
\end{aligned}
$$

$D+m_{2} m_{a} r^{2} \neq 0$ ならば，(1)式の左辺の行列は正則

で, (1)式より

$$
\dot{x}=f(x, u) \quad x=\left[\begin{array}{llll}
r & \theta & \dot{r} & \dot{\theta}
\end{array}\right]^{T}
$$

で表わされる非線形の状態方程式が得られる。 ベクト ル值関数 $f$ の形は，(1)式から明らかである.

固体摩擦による抵抗がない場合すなわち $C_{1 s}=C_{2 s}$ $=0$ のとき, $f(x, u)$ は $(x, u)=0$ のまわりでテイラ 一展開可能であり，てれを行うことにより(3)式はつ ぎの形に表わすととができる.

$$
\begin{aligned}
& \dot{x}=A x+b u+g(x, u) \\
& A=\left.\frac{\partial}{\partial x}\left[f(x, u) \mid \begin{array}{l}
C_{1 s}=0 \\
C_{2 s}=0
\end{array}\right]\right|_{\begin{array}{l}
x=0 \\
u=0
\end{array}}, \\
& b=\left.\frac{\partial}{\partial u}\left[f(x, u) \mid \begin{array}{l}
C_{1 s}=0 \\
C_{2 s}=0
\end{array}\right]\right|_{\substack{x=0 \\
u=0}}
\end{aligned}
$$

こてで, $g(x, u)$ は $C_{1 s}=C_{2 s}=0$ のとき $(x, u)$ の 2 次 以上の項からなるような関数である。 てのgを無視す ることにより，線形化した状態方程式が得られる.

行列 $A, b$ は特別な形をしているので, その部分行 列を用いると，線形化した状態方程式はさらにつぎの 形に書くことができる.

$$
\dot{x}_{1}=x_{2} \quad x_{1}=\left[\begin{array}{ll}
r & \theta
\end{array}\right]^{T}
$$

$$
\begin{aligned}
& >\dot{x}_{2}=A_{21} x_{1}+A_{22} x_{2}+b_{2} u \quad x_{2}=[\dot{r} \quad \dot{\theta}]^{T} \\
& A_{21}=\frac{g}{D}\left[\begin{array}{cc}
-m_{2} m_{b} & m_{2} I-m_{b} M_{0} \\
m_{2} m_{a} & m_{a} M_{0}-m_{2} m_{b}
\end{array}\right] \text {, } \\
& A_{22}=\frac{1}{D}\left[\begin{array}{cc}
-c_{2} I & c_{1} m_{b} \\
c_{2} m_{b} & -c_{1} m_{a}
\end{array}\right], \quad b_{2}=\frac{1}{D}\left[\begin{array}{c}
I \\
-m_{b}
\end{array}\right] \\
& \frac{x(s)}{u(s)}=(s E-A)^{-1} b=\frac{1}{d(s)}\left[\begin{array}{c}
n_{1}(s) \\
n_{2}(s) \\
s n_{1}(s) \\
s n_{2}(s)
\end{array}\right] \\
& n_{1}(s)=\frac{I G}{D}\left(s^{2}+\frac{c_{1}}{I} s-\frac{M_{0 g}}{I}\right) \triangleq \alpha_{1} s^{2}+\alpha_{2} s+\alpha_{3} \\
& n_{2}(s)=-\frac{m_{b} G}{D}\left(s^{2}-\frac{m_{2} g}{m_{b}}\right) \triangleq \beta_{1} s^{2}+\beta_{2} s+\beta_{3} \\
& d(s)=s^{4}+\frac{m_{a} c_{1}+I c_{2}}{D} s^{3} \\
& -\frac{\left(m_{a} M_{0}-2 m_{2} m_{b}\right) g-c_{1} c_{2}}{D} s^{2}-\frac{M_{0} c_{2} g}{D} s \\
& -\frac{m_{2}^{2} g^{2}}{D} \triangleq s^{4}+d_{1} s^{3}+d_{2} s^{2}+d_{3} s+d_{4}
\end{aligned}
$$

ここで, $E$ は単位行列, $d(s)$ は開ループの特性多項 式, $n_{1}(s), n_{2}(s)$ は $u$ 加 $r, \theta$ への伝達関数の分子多 項式である.

\section{4. 安定化制御}

本節では，前節で述べた倒立振子に関して，フィー ドバック制御によりこれを安定に倒立させる問題を理 論的に検討する. ての倒立振子システムは, 通常の仮 定のもとで (3)式により記述されるが，非線形である のでての安定化を直接検討するのは困難である.そこ でまず線形化した（5)式について考え，つぎに非線 
形系として取扱う。

\section{1 線形系としての安定化}

4.1.1 全状態フィードバック

線形系 (5)に扔いて，全状態量が検出可能な場合を 考える. 良く知られているように，定数線形系では完 全可制御性と状態フィードバックにより閉ループ極を 任意に設定できることとは等価である5 .したがって， 系 (5)が完全可制御なら，状態フィードバックにより 安定化できる. 系 (5)が完全可制御であるための必要 十分条件は，可制御行列 $\left[b, A b, A^{2} b, A^{3} b\right]$ が正則で あるとと，したがって，

$\left(m_{2} I-m_{b} M_{0}\right)^{2} g-c_{1}^{2} m_{2} m_{b} \neq 0$

が成立することである (( 7$)$ 式は，実際上 $G \neq 0$ であ るということを考慮している).

つぎに，線形系 (5)に状態フィードバック制御

$$
u=-k^{T} x \quad k=\left[\begin{array}{llll}
k_{1} & k_{2} & k_{3} & k_{4}
\end{array}\right]^{T}
$$

を行う場合に，閉ループ系の特性多項式が

$$
\left(s^{2}+2 \sigma_{1} s+\omega_{1}^{2}\right)\left(s^{2}+2 \sigma_{2} s+\omega_{2}^{2}\right)
$$

になるようなフィードバック係数 $k$ を求める式を導び

く. 閉ループ特性多項式は

$$
\begin{aligned}
\operatorname{det} & \left(s E-A+b k^{T}\right) \\
= & \operatorname{det}\left[(s E-A) \cdot\left\{E+(s E-A)^{-1} b k^{T}\right\}\right] \\
= & \operatorname{det}(s E-A) \cdot \operatorname{det}\left\{E+(s E-A)^{-1} b k^{T}\right\} \\
= & \operatorname{det}(s E-A) \cdot\left(1+k^{T}(s E-A)^{-1} \cdot b\right) \\
= & d(s)+k_{1} n_{1}(s)+k_{2} n_{2}(s)+k_{3} s n_{1}(s)+k_{4} s n_{2}(s)
\end{aligned}
$$

と計算されるから，(9)式と(10)式が恒等的に等しい ことより次式が得られる.

$$
\left[\begin{array}{c}
2\left(\sigma_{1}+\sigma_{2}\right) \\
\omega_{1}^{2}+\omega_{2}^{2}+4 \sigma_{1} \sigma_{2} \\
2\left(\sigma_{1} \omega_{2}^{2}+\sigma_{2} \omega_{1}^{2}\right) \\
\omega_{1}^{2} \omega_{2}^{2}
\end{array}\right]=\left[\begin{array}{l}
d_{1} \\
d_{2} \\
d_{3} \\
d_{4}
\end{array}\right]+\left[\begin{array}{cccc}
0 & 0 & \alpha_{1} & \beta_{1} \\
\alpha_{1} & \beta_{1} & \alpha_{2} & \beta_{2} \\
\alpha_{2} & \beta_{2} & \alpha_{3} & \beta_{3} \\
\alpha_{3} & \beta_{3} & 0 & 0
\end{array}\right]\left[\begin{array}{c}
k_{1} \\
k_{2} \\
k_{3} \\
k_{4}
\end{array}\right]
$$

乙てで, $\alpha_{i}, \beta_{i}, d_{i}$ は (6) 式で定義されるあのである. 可制御条件 (7) は，(11)式の右辺の $4 \times 4$ 行列が正則 であるための条件であある．したがって，条件 (7)が 成り立つとき，求める $k$ は次式で与えられる。

$$
\left[\begin{array}{l}
k_{1} \\
k_{2} \\
k_{3} \\
k_{4}
\end{array}\right]=\left[\begin{array}{cccc}
0 & 0 & \alpha_{1} & \beta_{1} \\
\alpha_{1} & \beta_{1} & \alpha_{2} & \beta_{2} \\
\alpha_{2} & \beta_{2} & \alpha_{3} & \beta_{3} \\
\alpha_{3} & \beta_{3} & 0 & 0
\end{array}\right]^{-1}\left[\begin{array}{c}
2\left(\sigma_{1}+\sigma_{2}\right)-d_{1} \\
\omega_{1}^{2}+\omega_{2}^{2}+4 \sigma_{1} \sigma_{2}-d_{2} \\
2\left(\sigma_{1} \omega_{2}{ }^{2}+\sigma_{2} \omega_{1}{ }^{2}\right)-d_{3} \\
\omega_{1}^{2} \omega_{2}{ }^{2}-d_{4}
\end{array}\right]
$$

\subsection{2 不完全状態フィードバック}

状態量の一部しか検出できない場合, 線形系 (5)の 安定化について考える. まず,，定数フィードバック制 御で安定化できるから゙うかが問題である，特別の場合
すなわち $m_{2 a}=m_{2 b}=c_{1}=c_{2}=0$ の場合に対しては，ど の一つの状態が欠けてむ定数フィードバックでは安定 化できないという結論が, 閉ループ特性多項式の係数 に関する考察加ら容易に得られる。一般の場合は困難 な問題であって，しかむ上記の事実からむし安定化可 能であったとしてむ, 十分な安定度を与えるのは困難 であろうと予想される。

つぎに，オブザーバを用いたフィードバック制御に より安定化させる問題を考える，ての場合，システム の可観測性が問題になる. 線形系 (5)の可観測性につ いて調べると，つぎの結果が得られた。

1) $r$ または $\dot{r}$ または対 $(r, \dot{r})$ を出力とするとき, 系 (5) が完全可観測であるための必要十分条件は，可 制御条件之一致し，不等式 (7) が成り立つことである.

2) $\theta$ または $\dot{\theta}$ または対 $(\theta, \dot{\theta})$ を出力するとき，系

(5)苧全可観測であるための必要十分条件は,

$m_{2} m_{a}^{2} g-c_{2}^{2} m_{b} \neq 0$

が成り立つととである.

3) 対 $(r, \theta)$ または対 $(\dot{r}, \dot{\theta})$ を出力とするとき, 系 (5)は無条件で完全可観測である.

なお，乙てでは $m_{2} \neq 0$ を暗黙に仮定している.

良く知られているように，一般に定数線形系は完全 可制御かつ完全可観測なら，オブザーバを用いたフィ 一ドバック制御により安定化可能である。ここでは,

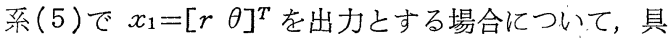
体的に考えると， 4 状態 2 出力であるから, 最小次元 オブザーバの次元は， 4-2=2 である. これには，つ ぎの Gopinath による最小次元オブザーバ6)を用いる のが，設計に便利である.

$$
\begin{aligned}
& \dot{z}=A_{21} x_{1}+\left(A_{22}-L\right) \hat{x}_{2}+b_{2} u \\
& \hat{x}_{2}=z+L x_{1}
\end{aligned}
$$

こてで， $\hat{x}_{2}$ は $x_{2}$ の推定值， $L$ は $2 \times 2$ 行列で設計パ ラメータである. 操作量は, 推定された状態量を用い て (8)式で構成する.このとき閉ループ系の方程式 は，(5)，(8)，(14)式をまとめるとつぎの形になる.

$$
\begin{aligned}
& {\left[\begin{array}{c}
\dot{x} \\
\dot{e}
\end{array}\right]=\left[\begin{array}{cc}
A-b k^{T} & -b k_{(2)}{ }^{T} \\
0 & A_{22}-L
\end{array}\right]\left[\begin{array}{l}
x \\
e
\end{array}\right]} \\
& e \triangleq \hat{x}_{2}-x_{2}, \quad k_{(2)}=\left[k_{3}, k_{4}\right]^{T}
\end{aligned}
$$

したがって，閉ループ極は行列 $A-b k^{T}$ と $A_{22}-L$ の 固有值からなる，乙の二つの行列のすべての固有值の 実部が負になるように，パラメータ $k, L$ を定めると， 閉ループ系を安定化できる，乙のような $k$ の選択は， 可制御条件 (7)が満たされていれば，(12)式により可 能であり，またLの選択は明らかに可能である.

\section{2 非線形系ししての安定化}

非線形系 (3) または (4)をフィードバック制御によ 
り安定化させる問題を考える，軸受などに固体摩 擦が存在しない場合すなわち $C_{1 s}=C_{2 s}=0$ の場合 に対し，4.1 で述べた線形系(5)を安定化させる 制御方策が，非線形系 (3)または (4)をむ安定化 させることを示すととができる. 状態フィードバ ックの場合と $x_{1}=[r, \theta]^{T}$ のオブザーバを用いた フィードバックの場合について, とのととを示す.

非線形系 (4) 亿状態フィードバック制御 (8)を行う 場合, 拉よび $x_{1}$ を出力として最小次元オブ,ザーバ （14）を用いたフィードバック制御(8)老行う場合, 閉 ループ系はそれぞれつぎの (16)，(17)式で表わされる.

$$
\begin{aligned}
\dot{x}= & \left(A-b k^{T}\right) x+g\left(x,-k^{T} x\right) \\
{\left[\begin{array}{c}
\dot{x} \\
\dot{e}
\end{array}\right]=} & {\left[\begin{array}{cc}
A-b k^{T} & -b k_{(2)}{ }^{T} \\
0 & A_{22}-L
\end{array}\right]\left[\begin{array}{c}
x \\
e
\end{array}\right] } \\
& +\left[\begin{array}{c}
g\left(x,-k^{T} x-k_{(2)} e\right) \\
-g(2)\left(x,-k^{T} x-k_{(2)}{ }^{T} e\right)
\end{array}\right]
\end{aligned}
$$

ここで

$$
g(2) \triangleq\left[g_{3}, g_{4}\right]^{T}, \quad g=\left[g_{1}, g_{2}, g_{3}, g_{4}\right]^{T} .
$$

3 節で述べたように, $g(x, u)$ は $C_{1 s}=C_{2 s}=0$ のとき $(x, u)=0$ のまわりにティラー展開可能で 2 次以上の 項からなる，したがって，乙のとき系(16)，(17)の非 線形項もそれぞれ，状態量の 2 次以上の項からなる. てのような場合, 線形部分のすべての固有值が負の実 部をむつならば，非線形系(16)，(17）の平衡点である 原点は漸近安定である77.

軸受などに固体摩擦が存在する場合には, 非線形項 $g(x, u)$ が $x=0$ で不連続となり上の議論は成り立た ないが，固体摩擦は小さいむのと考光られるから，て れを無視した考察による安定化制御の方式で, 一応安 定化が達成できるむのと思われる. 固体摩擦の影響に

Table 1 Estimated parameters of the experimental system

\begin{tabular}{ll}
\hline \multicolumn{1}{c}{$\quad$ Pendulum } & \\
Mass moment & $M_{0} 6.29 \mathrm{~kg} \cdot \mathrm{m}$ \\
Moment of inertia & $I 6.03 \mathrm{~kg} \cdot \mathrm{m}^{2}$ \\
Friction coefficient & $c_{1} 0.115 \mathrm{~kg} \cdot \mathrm{m}^{2} / \mathrm{sec}$ \\
Moment by dry friction & $C_{1 s} 0.0410 \mathrm{~N} \cdot \mathrm{m}$ \\
(Mass & $m_{1}$ about $\left.9 \mathrm{~kg}\right)$ \\
(Length to the gravity center & $l_{1}$ about $0.63 \mathrm{~m}$ ) \\
\hline \multicolumn{1}{c}{ Weight } & \\
Mass & $m_{2} 1.21 \mathrm{~kg}$ \\
Length to the gravity center & $l_{2} 0.5176 \mathrm{~m}$ \\
Equivalent mass & $m_{a} \cdot 2.27 \mathrm{~kg}$ \\
Equivalent mass moment & $m_{b} 0.643 \mathrm{~kg} \cdot \mathrm{m}$ \\
Equivalent friction constant & $c_{2} 24.6 \mathrm{~kg} / \mathrm{sec}$ \\
Force by dry friction & $C_{2 s} 3.08 \mathrm{~N}$ \\
Equivalent gain constant & $G 80.7 \mathrm{~N} / \mathrm{V}$ \\
\hline
\end{tabular}

Table 2 Coefficients of linearized state equation

$$
\begin{aligned}
& A_{21}=\frac{g}{D}\left[\begin{array}{cc}
-m_{2} m_{b} & m_{2} I-m_{b} M_{0} \\
m_{2} m_{a} & m_{a} M_{0}-m_{2} m_{b}
\end{array}\right]=\left[\begin{array}{cc}
-0.573(1 / \mathrm{sec}) & 2.39(\mathrm{~m} / \mathrm{sec}) \\
2.03(1 / \mathrm{m} \cdot \mathrm{sec}) & 9.97(1 / \mathrm{sec})
\end{array}\right] \\
& A_{22}=\frac{1}{D}\left[\begin{array}{cc}
-c_{2} I & c_{1} m_{b} \\
c_{2} m_{b} & -c_{1} m_{a}
\end{array}\right]=\left[\begin{array}{cc}
-11.2(1 / \mathrm{sec}) & 0.00554(\mathrm{~m} / \mathrm{sec}) \\
1.19(1 / \mathrm{m} \cdot \mathrm{sec}) & -0.0196(1 / \mathrm{sec})
\end{array}\right] \\
& b_{2}=\frac{G}{D}\left[\begin{array}{c}
I \\
-m_{b}
\end{array}\right]=\left[\begin{array}{c}
36.6(\mathrm{~m} / \mathrm{sec} \cdot \mathrm{V}) \\
-3.90(1 / \mathrm{sec} \cdot \mathrm{V})
\end{array}\right]
\end{aligned}
$$

ついては，実験で調べてみることにする.

最後に，本節で述べた安定化制御の存在の前提であ る可制御条件 (7) は等式が不成立という条件であるか ら, ほとんぞの場合ての条件は満たされ，したがって 安定化可能であるといえる. しかし，乙れは操作量の 大きさに制限がないと考えた議論であり, 実際には増 幅器の飽和や電動機の能力により, 操作量に拘束があ るので(7)式の左辺がゼロに近い場合には，(12)式で 計算されるフィードバック係数が非常に大きな值とな り，実際上安定化できないととが生ずる.

\section{5. 安定化制御実験と考察}

実験に用いた倒立振子のパラメータの測定值を Table 1 亿示す．I, $c_{1}, C_{1}$ 仙微小角自由振動加ら， $c_{2}$, $C_{2 s}$ はステップ応答から求めた. 線形化した状態方程 式のパラメータを Table 2 亿，伝達関数のパラメータ を Table 3 亿示す.

実験は $x_{1}=[r, \theta]^{T}$ を出力として検出しているの で，最小次元オブザーバ(14)をアナログ計算機 (NEC A-300) で構成して，フィードバック制御を行った. 安定化制御器のパラメータ $k, L$ は閉ループ極を設定 することにより定めた．安定に倒立した振子の応答の 例を Fig. 4 に，てれに用いた制御器のパラメータを Table 4 に，そのアナログ計算機の回路図の例を Fig. 5 亿示す.

Fig. 4 は，オブザーバの極を $-12 ，-15$ 亿固定し， 閉ループ極を $-3 ，-4 ，-5$ (それぞれ 4 重根）之変 化させたときの応答を示している，固体摩擦によるむ のと考えられる持続振動が生じているが，極を $s$ 平面 のより左に設定すると，乙の振幅は小さくなる傾向が ある.また，(b)，(c) の高い波形の部分は，外乱を 与えたために生じたあのであり，外乱に対し十分な安 定度をむっているととを示している。

同じオブザーバを用い閉ループ極が -2 のときには

Table 3 Transfèr function

$$
\begin{aligned}
& \frac{r(s)}{u(s)}=\frac{36.6(s+3.21)(s-3.19)}{(s+11.1)(s+3.20)(s+0.09)(s-3.20)} \\
& \frac{\theta(s)}{u(s)}=\frac{-3.90(s+4.29)(s-4.29)}{(s+11.1)(s+3.20)(s+0.09)(s-3.20)}
\end{aligned}
$$




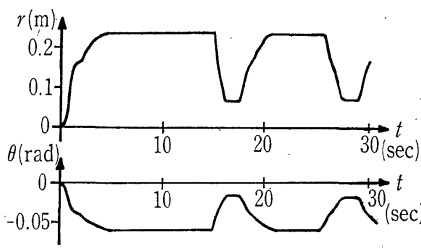

(a) Closed Loop Poles; -3

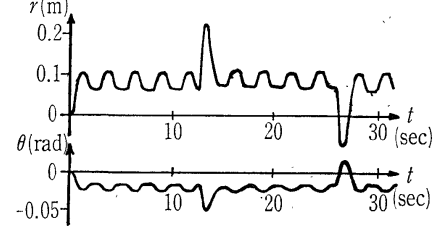

(b) Closed Loop Poles; -4

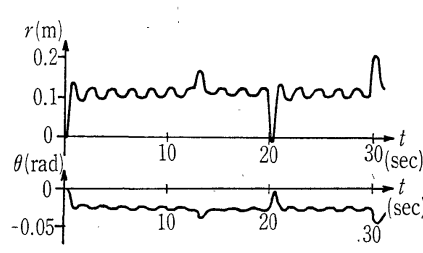

(c) Closed Loop Poles; -5

Fig. 4 Practical response $r$ : weight position $\theta$ : pendulum angle

Table 4 Parameters of minimum order observer controller

\begin{tabular}{|c|c|c|c|c|}
\hline Observer parameters & $L=$ & $\left.\begin{array}{ll}84 & 0.006 \\
19 & 12.0\end{array}\right]$ & & \\
\hline \multicolumn{5}{|c|}{ Observer poles $-12,-15$} \\
\hline & & Feedba & law & \\
\hline Closed loop poles & $\begin{array}{c}k_{1} \\
(\mathrm{~V} / \mathrm{m})\end{array}$ & $\begin{array}{c}k_{2} \\
\text { (V/rad) }\end{array}$ & $\begin{array}{c}k_{3} \\
(\mathrm{~V} /(\mathrm{m} / \mathrm{s}))\end{array}$ & $(\mathrm{V} /(\mathrm{rad} / \mathrm{s}))$ \\
\hline-3 (multiplicity 4 ) & 4.148 & 22.87 & 0.7803 & 7. 111 \\
\hline-4 (multiplicity 4 ) & 7.277 & 41.57 & 1.511 & 12.95 \\
\hline-5 (multiplicity 4 ) & 11. 77 & 70.14 & 2.559 & 21.75 \\
\hline
\end{tabular}

$\dot{r}, \dot{\theta}$ を微分器を用いて求め, 状態フィ 一ドバックを行う場合についてむ，実験

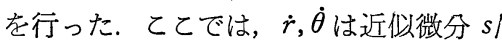
$\left(1+T_{i} s\right)$ で求め, 操作量はフィルタ $1 /$ $\left(1+T_{0} s\right)$ を通して入力とした，安定化で きるかどうかは， $T_{i}, T_{0}$ の值に依存し， $T_{i}$ が $0.1 \sim 0.01$ 秒， $T_{0}$ が 0.05 秒の時 には良い応答が得られた。 $T_{i}, T_{0}$ の值 を変えて行った実験の結果を Table 5 に 示す。.

Fig. 4 の応答に見られるように，オブ ザーバを用いたフィードバック制御にお いても微分器を用いたフィードバック制 御のどちらにおいても; 持続振動の中心が $r=\theta=0$ からずれるということが生じた。 こ れは，ポテンショのゼロ点設定の誤差，アナ ログ計算機の精度，摩擦の不均一性などによ るものと考えられるが，乙の原因を除去する のは，非常に困難である，積分補償で偏差を ゼロにするととができることは，古典的制御 論で良く知られており，乙こであ，制御系に $\theta$ の積分フィードバックを追加するととによ

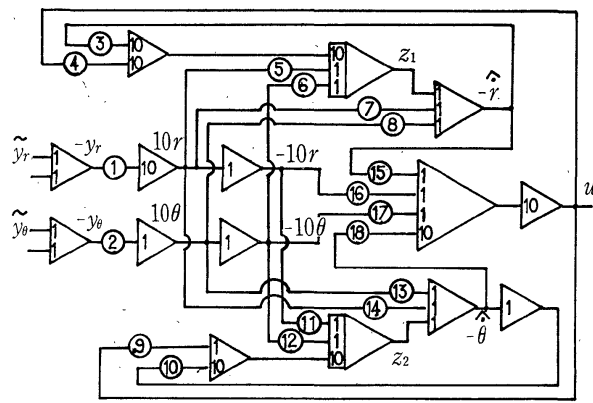

Fig. 5 Analog circuit of the observer-controller when the closed loop poles are all -5 and observer poles $-12,-15$

Potentiometers: (1): 0.1276 , (2): 0.5092 , (3): 0.1500 , (4): 0.3660 , (5): 0.0573 , (6): 0.2390 , (7): 0.3840 , (8): 0.0006 , (9): 0.3900 , (10): 0.1200 , (11): 0.2030 , (12): 0.9970 , (13): 0.1200 , (14)0.1190, (15): 0.2559 , (16): 0.1177 , (17): 0.7014 , (18): 0.2175

安定とならなかった. これは持続振動の振幅が大き 〈て，実験装置の拘束 $|u| \leq$ 約 $0.6[\mathrm{~V}],|r| \leq$ 約 0.8 〔m〕およびアナログ計算機の電圧制限 $( \pm 10 \mathrm{~V})$ のい ずれかを超えたためと考えられる．また一般に安定化 できた場合む，初期状態として倒立の平衡状態もしく はこれに近い状態を選ばないと安定に倒立させること はできなかった．乙れあ同様にこれらの拘束のためと 考えられる.
り，てのずれをゼロにするととができた．さらに， $\theta_{d}-\theta$ の積分フィードバックを行う場合には，持続振 動の中心点を, 目標値 $\theta_{d}$ に従って可能な範囲で自由 に変えることができた。

最後に，倒立振子の応答に生じた持続振動は，固体 摩擦によるものと考えられるので，記述関数法を用い ててれを解析する．操作部系統の固体摩擦力を $F_{r} \triangleq$ $-C_{2 s} \operatorname{sgn}(\dot{r})[\mathrm{N}]$, 支持軸の固体摩擦トルクを $F_{\theta} \triangleq$ $-C_{1 s} \operatorname{sgn}(\dot{\theta})[\mathrm{N} \cdot \mathrm{m}]$ とする. $F_{r} / G$ 加ら $\dot{r} へ の$ 伝達 関数は, 状態フィードバック制御 $(8)$ を行っている時 には,

$$
S_{r}(s) \triangleq \frac{\dot{r}(s)}{F_{r}(s) / G}=\frac{s n_{1}(s)}{d_{c}(s)}
$$

オブザーバ(14)を用いたフィードバック制御（8)の時 には,

$$
S_{r}(s)=\frac{s n_{1}(s)\left\{1+k_{(2)}{ }^{T}\left(s I-A_{22}+L\right)^{-1} b_{2}\right\}}{d_{c}(s)}
$$

亡なる.乙こで $d_{c}(s)$ は閉ループ系の特性多項式, $n_{1}(s), A_{22}$ はそれぞれ，（6)式，および(5)式で与え られる。また， $\dot{r}$ からーFr/Gへの記述関数は，

$$
N_{r}(a)=\frac{4 C_{2 s}}{\pi G a}
$$

となる. ここで $a$ は $\dot{r}$ の振幅である. $S_{r}(j \omega)$ のナイ キスト軌跡と $N_{r}(a)$ の逆記述関数軌跡を Fig. 6 に 
Table 5 Experimental result for the case of state feedback where $\dot{r}$, $\dot{\theta}$ is computed by aproximate differentiator $s /\left(1+T_{i} s\right)$ and control is filtered by $1 /\left(1+T_{o} s\right)$ when closed loop poles are all -5

\begin{tabular}{c|l|l|l}
\hline \hline$T_{0}$ & \multicolumn{1}{|c|}{$0.1 \mathrm{sec}$} & \multicolumn{1}{|c}{$0.01 \mathrm{sec}$} & \multicolumn{1}{c}{$0.005 \mathrm{sec}$} \\
\hline $\begin{array}{c}0.05 \\
\text { sec }\end{array}$ & $\begin{array}{l}\text { Stable } \\
\text { Limit cycle } \\
(0.037 \mathrm{~m}, 1.69 \mathrm{sec})\end{array}$ & $\begin{array}{l}\text { Stable } \\
\text { Stand still }\end{array}$ & $\begin{array}{l}\text { Stable } \\
\text { Stand still }\end{array}$ \\
\hline $\begin{array}{c}0.005 \\
\text { sec }\end{array}$ & $\begin{array}{l}\text { Stable } \\
\text { Stand still }\end{array}$ & $\begin{array}{l}\text { Stable, but high } \\
\text { frequency, small } \\
\text { amplitude ocilation } \\
\text { exists. } \\
\text { Unstable for large } \\
\text { disturbance }\end{array}$ & $\begin{array}{l}\text { Unstable } \\
\text { High frequency, } \\
\text { small amplitude } \\
\text { ocilation exists. }\end{array}$ \\
\hline $0 \mathrm{sec}$ & $\begin{array}{l}\text { Stable } \\
\text { Stand still }\end{array}$ & $\begin{array}{l}\text { Stable, but high } \\
\text { frequency, small } \\
\text { amplitude severe } \\
\text { ocilation exists. } \\
\text { Limit cycle of large } \\
\text { amplitude also exists. } \\
\text { Unstable for small } \\
\text { disturbance. }\end{array}$ & Unstable \\
\hline
\end{tabular}

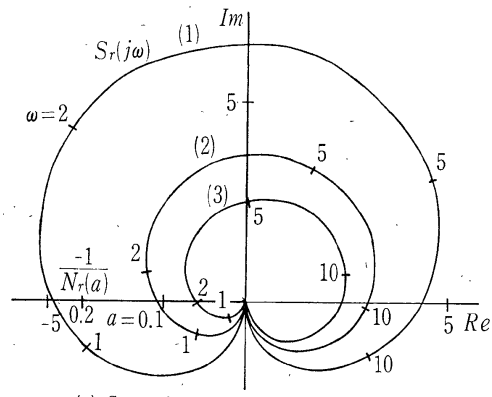

(a) State feedback case; equation (18) and (20).

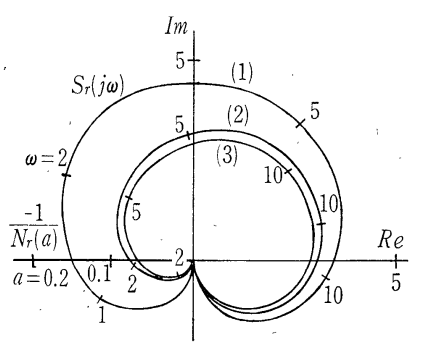

(b) Obsever-controller case; equation (19) and (20).
Fig. 6 Nyquist locus of $S_{r}(j \omega)$ and inverse describing function locus of $N_{r}(a)$ when the closed loop poles are all -3 to curve (1), all -4 to curve (2), and all -5 to curve (3)

Table 6 Comparison between experimental result and analysis by the describing function method, of the limit cycle. At describing function analysis, dry friction $C_{2 s}=3.08 \mathrm{~N}$ is only considered. At state feedback experiment using differentiator, $T_{i}$ is $0.01 \mathrm{sec}$ and $T_{o}$ is $0.05 \mathrm{sec}$. At observer-controller case, observer poles are $-12,-15$

\begin{tabular}{|c|c|c|c|c|c|}
\hline \multirow{2}{*}{$\begin{array}{l}\text { Closed loop } \\
\text { poles }\end{array}$} & \multirow{2}{*}{ 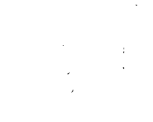 } & \multicolumn{2}{|c|}{ State feedback } & \multicolumn{2}{|c|}{ Observer-controller } \\
\hline & & $\begin{array}{l}\text { Experiment Using } \\
\text { differentiator }\end{array}$ & $\begin{array}{l}\text { Describing function } \\
\text { method }\end{array}$ & Experiment & $\begin{array}{l}\text { Describing function } \\
\text { method }\end{array}$ \\
\hline all -3 & $\begin{array}{l}\text { Period } \\
\text { Amp. of } r \\
\text { Amp. of } \theta\end{array}$ & $\begin{array}{l}8 \mathrm{sec} \\
0.19 \mathrm{~m} \\
0.036 \mathrm{rad}\end{array}$ & $\begin{array}{l}5.06 \mathrm{sec} \\
0.188 \mathrm{~m} \\
0.034 \mathrm{rad}\end{array}$ & $\begin{array}{l}11 \mathrm{sec} \\
0.085 \mathrm{~m} \\
0.02 \mathrm{rad}\end{array}$ & $\begin{array}{l}4.59 \mathrm{sec} \\
0.112 \mathrm{~m} \\
0.02 \mathrm{rad}\end{array}$ \\
\hline all -4 & $\begin{array}{l}\text { Period } \\
\text { Amp. of } r \\
\text { Amp. of } \theta\end{array}$ & $\begin{array}{l}6 \mathrm{sec} \\
0.04 \mathrm{~m} \\
0.008 \mathrm{rad}\end{array}$ & $\begin{array}{l}3.80 \mathrm{sec} \\
0.066 \mathrm{~m} \\
0.011 \mathrm{rad}\end{array}$ & $\begin{array}{l}2.5 \mathrm{sec} \\
0.023 \mathrm{~m} \\
0.004 \mathrm{rad}\end{array}$ & $\begin{array}{l}2.98 \mathrm{sec} \\
0.036 \\
0.006 \mathrm{rad}\end{array}$ \\
\hline all -5 & $\begin{array}{l}\text { Period } \\
\text { Amp. of } r \\
\text { Amp. of } \theta\end{array}$ & 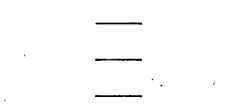 & $\begin{array}{l}3.04 \mathrm{sec} \\
0.030 \mathrm{~m} \\
0.0050 \mathrm{rad}\end{array}$ & $\begin{array}{l}1.9 \mathrm{sec} \\
0.012 \mathrm{~m} \\
0.002 \mathrm{rad}\end{array}$ & $\begin{array}{l}1.77 \mathrm{sec} \\
0.019 \mathrm{~m} \\
0.0028 \mathrm{rad}\end{array}$ \\
\hline
\end{tabular}

示す．両軌跡の交点から，持続振動の 周期と振幅が推定できる. この解析結 果と実験との比較を Table 6 亿示す.

解析結果は実験に，だいたい良く合っ ているといえる.

つぎに， $F_{\theta}$ から $\dot{\theta}$ への伝達関数は， 状態フィードバック制御 (8)を行って いる時には,

$$
\begin{aligned}
& S_{\theta}(s) \triangleq \frac{\dot{\theta}(s)}{F_{\theta}(s) / G} \\
& =\frac{s\left\{f_{\theta}(s)+\frac{G}{D}\left(k_{1}+k_{3} s\right)\right\}}{d_{c}(s)}
\end{aligned}
$$

オブザーバ(14)を用いたフィードバッ ク制御 (8)の時には,

$$
\begin{aligned}
& S_{\theta}(s)=\frac{s\left\{f_{\theta}(s)+\frac{G}{D}\left(k_{1}+k_{3} s\right)\right.}{d_{c}(s)} * \\
& \left.+n_{2}(s) k_{(2)}{ }^{T}\left(s I-A_{22}+L\right)^{-1} b_{\theta}\right\}
\end{aligned}
$$

となる. こてで, $f_{\theta}(s)$ は, $F_{\theta}$ から $\theta$ への開ループ伝達関数の分子多項式, また $b_{\theta}{ }^{T} \triangleq\left[-m_{b} / D m_{a} / D\right]$ である. $\dot{\theta}$ から $-F_{\theta}$ への記述関数は，

$$
N_{\theta}(a)=\frac{4 C_{1 s}}{\pi a}
$$

となる.とこで $a$ は $\dot{\theta}$ の基本波の振幅 である. $S_{\theta}(j \omega)$ のナイキスト軌跡と $N_{\theta}(a)$ の逆記述関数軌跡を Fig. 7 に 示す. との場合交点がないので, リミ ットサイクルは生じない. 


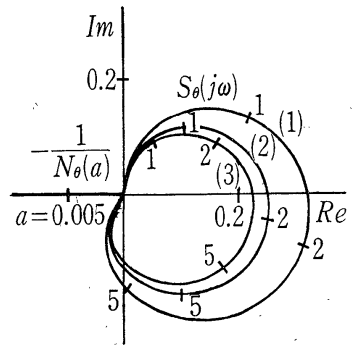

(a) State feedback case

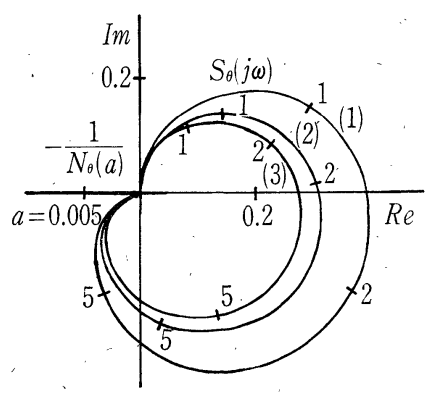

(b) Obsever-controller case
Fig. 7 Nyquist locus of $S_{\theta}(j \omega)$ and inverse describing function locus of $N_{r}(a)$ when the closed loop poles are all -3 to curve (1), all -4 to curve (2), and all -5 to curve (3)

以上の記述関数による解析から，つぎの事が推定さ れる、リミットサイクルが生ずる主な原因は，操作部 系統の固体摩擦 $F_{r}$ であり, 支持軸の固体摩擦トルク $F_{\theta}$ のみの存在ではリミットサイクルは生じない。リ ミットサイクルの振幅は, $F_{r}$ の大きさ $C_{2 s}$ に比例し, 周期は $C_{2 s}$ によっては変化しない，また，閉ループ極 を $s$ 平面でより左に移動させるととにより, リミット サイクルの振幅は小さくできる.

\section{6. むすび}

内部でおすりを左右に移動させる方式による倒立振 子の姿勢制御について, 理論的かつ実験的検討を行っ た.こてでは，乙の形式の倒立振子が軸受などに固体 摩擦がないならば，ほとんどの場合満たされる条件の あとで，理論的に安定化可能であるととを示した．と の条件とは, 線形化した状態方程式の可制御条件 (7) および可観測条件 (7)，(13) であり；可制御条件が満 たされるならば状態フィードバックにより，可観測条 件が満たされるならば出力のオブザーバを用いたフィ 一ドバックにより，安定化することができる．ただ し，実際には操作量に拘束があるので，(7)式の左辺 がゼロに近い場合安定化が困難であると考えられる。

実験では $(r, \theta)$ を出力とし， 2 次の最小次元オブザ 一バを用いて，( $\dot{r}, \dot{\theta})$ を推定し，フィードバック制御 を行った.てての結果, 安定に倒立させることができ, 軸受などの固体摩擦は小さく安定化に影響を与えない 程度であろうとの予想が裹付けられた。 またオブザー バあ有効に㗢いたものと考えられる.

微分器を用いて $\dot{r} と \dot{\theta}$ を求めて, 状態フィードバッ ク制御を行う場合も検討した. 近似微分 $s /\left(1+T_{i} s\right)$ の $T_{i}$ が $0.1 \sim 0.01$, 操作量のフィルタ $1 /\left(1+T_{0} s\right)$ の $T_{0}$ が 0.05 などの值で, 安定に倒立させるととが できた. $T_{i}, T_{0}$ がこれより小さな值の時には，高周波
微小振幅の振動が生じ，安定に倒立した場合む 小さな外乱で倒れた. オブザーバを用いたフィ ードバック制御は，乙のようなフィルタの問題 を考えずにストレートに設計可能で，しかす外 乱に対し十分安定であるので，設計手法として 非常に有効であると考えられる.

安定化された倒立振子の応答には持続振動が 生じたが，記述関数法による解析から，乙の主 な原因は，操作部系統におりる固体摩擦である ことがわかった．また，閉ループ極を $s$ 平面で より左に移動させると, この振幅は小さくなる. しかし，操作量には拘束があるので，むやみに 根を左に移動させるわけにはいかない.したが って，振幅を小さくするか，振動をなくする別の方法 が必要である，摩擦は温度や接触面の状態などによっ て変化するので，適応的な補償が望ましく，今後の課 題である.

単なる状態フィードバックなどでは，持続振動の中 心点が $r=\theta=0$ からずれたが，乙れは， $\theta$ の積分フィ ードバックを付加することにより解決した.

安定化の重要な前提である可制御条件 (7) は， $m_{2 a}$ $=m_{2 b}=I_{2}{ }^{\prime}=c_{1}=0$ のとき $I_{1}{ }^{\prime} \triangleq m_{1} R_{1}{ }^{2}$ とすると $l_{1}\left(l_{2}-\right.$ $\left.l_{1}\right) \neq R_{1}{ }^{2}$ の形になる. これは，打むりの移動する軌道 が，振子の支点に対する打撃の中心を通らないという ことであり, 支点の反力の水平方向の成分が, 安定化 の重要な要因であることを示唆している.

最後に，倒立振子の制御について貴重なで意見をく ださった東京工業大学 古田勝久氏ならびに森正三氏 に深く感謝する，また，本研究に協力を得た大阪大学 大学院生 平子敬一君に感謝する.

\section{参 考 文 献}

1) H. Hemami, W. C. Weimer and S.H. Koozekanami : Some Aspect of the Inverted Pendulum Problem for Modelling of Locomotion Systems, JACC Preprint, 132/140 (1973)

2) C. L. Golliday and H. Hemami : Postural Stability of the Two-Degree-of-Freedom Biped by General Linear Feedback, IEEE Trans. on Automatic Control, AC-21-1, 74/79 (1976)

3）酒井，江村：重心移動による倒立振子の姿勢制御，精密 機械学会東北支部講演会前刷，9/12 (1972)

4) 酒井, 江村：反動力によって立位を維持する倒立振子の 研究「バイオメカニズム2」, 321/328 (1973)

5) W.H. Wonham: On Pole Assignment in MultiInput Controllable Linear Systems, IEEE Trans. on Automatic Control, AC-12-6, 660/665 (1967)

6) 有本: 線形システム理論, 180, 産業図書 (1974)

7) J. LaSalle and S. Lefschetz 著, 山本訳: リアプノフ の方法による安定性理論，41，産業図書 (1975) 